\title{
Pengaruh Lingkungan Belajar Dan Konsep Diri Terhadap Hasil Belajar Biologi Siswa SMP Negeri I Maluku Tengah
}

\author{
Pebrywati Watimury ${ }^{1}$, Farida bahalwan ${ }^{2}$ \\ ${ }^{1}$ Program Studi Pendidikan Biologi, Fakultas Keguruan dan Ilmu Pendidikan, \\ ${ }^{1,2}$ Universitas Darussalam Ambon \\ ${ }^{1}$ Email: pebrywatiwatimury88@gmail.com
}

\begin{abstract}
Abstrak Tujuan penelitian ini adalah mengetahui pengaruh lingkungan belajar terhadap hasil belajar biolog isiswa SMP Negeri I Maluku Tengah. Mengetahui pengaruh konsep diri terhadap hasil belajar biologi siswa SMP Negeri I Maluku Tengah dan mengetahui pengaruh lingkungan belajar dan konsep diri secara bersama-sama terhadap hasil belajar biologi siswa SMP Negeri I Maluku Tengah. Jenis penelitian ini adalah penelitian expostfacto dengan teknik pengumpulan data melalui angket dan nilai tes siswa teknik analisis data secara deskriptif dan inferensial (regresi ganda). Hasil menunjukan bahwa. (1) terdapat pengaruh yang signifikan antara lingkungan belajar terhadap hasil belajar biologi siswa SMP Negeri I Maluku Tengah, (2) terdapat pengaruh yang signifikan antara Konsep diri terhadap hasil belajar biologi siswa, dan (3) terdapat pengaruh yang signifikan antara Lingkungan belajar dan konsep diri secara bersamaan terhadap prestasi belajar biologisiswa.
\end{abstract}

Kata Kunci: Lingkungan Belajar, Konsep Diri, Hasil Belajar.

Abstract: The purpose of this study was to determine the effect of the learning environment on the learning outcomes of Central Moluccas I Middle School student biologists. Knowing the effect of self-concept on the biology learning outcomes of students of Central Maluku Middle School I and find out the effect of the learning environment and self-concept together on the biology learning outcomes of Central Maluku Middle School I students. This type of research is ex-postfacto research with data collection techniques through questionnaires and student test scores of descriptive and inferential data analysis techniques (multiple regression). The results show that. (1) there is a significant influence between the learning environment on the biology learning outcomes of Central Maluku Middle School I students, (2) there is a significant influence between self-concept towards student biology learning outcomes, and (3) there is a significant influence between the learning environment and simultaneously on the achievement of biology learning.

Key Words: Learning Environment, Self Concept, Learning Outcomes. 
Faktor-faktor yang dapat menentukan hasil belajar antara satu siswa dengan siswa yang lainnya pasti berbeda. Pencapaian hasil belajar yang maksimal merupakan tujuan dari setiap kegiatan belajar tetapi pada kenyataannya masih terdapat siswa yang kurang berprestasi. Setiap lingkungan belajar memiliki pengaruh yang berbeda terhadap hasil belajar siswa, dalam meningkatkan hasil belajar, tidak semua lingkungan belajar berpengaruh positif bila tidak didukung dengan konsep diri siswa itu sendiri. Banyak faktor yang mempengaruhi hasil belajar siswa yang secara garis besar dikelompokan menjadi dua macam yaitu faktor yang berasal dari dalam diri sisiwa (intern) yang meliputi kecerdasan, bakat, minat, perhatian, motivasi kesehatan jasmani, emosi, kesiapan dan kemaun belajar. Sedangkan faktor yang berasal dari luar diri siswa (extern) meliputi lingkungan belajar anak yaitu perhatian orang tua dan kondisi lingkungan keluarga.

Hasil belajar siswa dalam pendidikan dipengaruhi oleh beberapa faktor yang ada pada diri siswa itu sendiri, baik faktor diri dalam yaitu konsep diri maupun faktor yang berada disekitar siswa yaitu lingkungan belajar. Adapun kondisi nyata lapangan dimaksud adalah seperti potensi siswa, kondisi sarana dan prasarana pendidikan, termasuk lingkungan internal dan eksternal sekolah.

Faktor external berupa lingkungan belajar tidak lepas dari keberadaan siswa yang belajar. Kebiasaan belajar siswa dipengaruhi oleh kebiasaan siswa belajar disekolah,di rumah, maupun di masyarakat. Kebiasaan belajar yang efektif berdampak pada lingkungan siswa, lingkungan belajar yang baik harus diikuti dengan penguatan yang diberikan oleh guru yang maksimal pula. Lingkungan belajar oleh para ahli yaitu tempat berlangsungnya kegiatan belajar yang mendapat pengaruh dari luar terhadap keberlangsungan kegiatan tersebutlingkungan pendidikan antara lain mencakup, lingkungan keluarga, lingkungan sekolah dan lingkungan masyarakat.

Proses belajar tidak lepas dari salah satu faktor internalnya dalam hal ini konsep diri siswa. Konsep diri diperlukan untuk siswa, agar pandangan dan perasaan siswa terhadap dirinya sendiri baik secara psikologi,sosial maupun fisik dapat tertanam.Konsep diri yang positif ini kemudian melandasi perkembangan rasa percaya diri pada individu akan mempengaruhi penilian pada diri sendiri bila sesorang menilai dirinya sendiri secara positif, maka seseorang akan dapat mengaktualisasikan diri dengan penuh rasa percaya diri. Siswa yang memiliki konsep diri negatif juga cenderung menganggap situasi baru sebagai bahaya, pesimis dan selalu menganggap dirinya kurang berharga. Perkembangan konsep diri tidak terjadi dengan sendirinya, Konsep diri terbentuk sejak dini atau pada masa kanak-kanak yaitu sejak kemampuan presepsi seseorang mulai berfungsi secara terus-menerus melalui proses belajar serta nilai yang diperoleh melalui orang-orang yang berarti dalam hidupnya. Konsep diri yang positif mampu menumbuhkan keyakinan pada diri setiap individu. Sehingga dalam menumbuhkan konsep diri siswa, maka diperlukan peran dari lingkungan belajar anak yaitu lingkungan keluarga, lingkungan sekolah dan lingkungan masyarakat.

BIOLOGI SEL (VOL 8 NO 1 EDISI JAN-JUN 2019 ISSN 2252-858X/E-ISSN 2541-1225) PAGE 43 
Kedua faktor internal dan external diatas saling mempengaruhi dan menentukan hasil belajar.Siswa yang memiliki konsep diri tinggi dan didukung dengan lingkungan belajar yang baik, akan menunjang tindakan positif seperti selalu mensyukuri kondisinya, menjaga kesopanan dan kesantunan dalam berkomonikasi bersemangat dalam belajar, selalu ingin menjadi yang terbaik serta kreatif dan inovatif. Sebaliknya siswa yang memiliki konsep diri yang rendah serta didukung dengan lingkungan belajar yang buruk tentunya akan memiliki hasil belajar yang rendah pula.

\section{METODE PENELITIAN}

Penelitian adalah penelitian ex-postfactodirancang untuk mengetahui keterkaitan antara variabel bebas dengan variabel terikat. Peneliti dalam hal ini akan menelusuri pengaruh lingkungan belajar, konsep diri. Terhadap hasil belajar dan tidak memberikan perlakuan-perlakuan tertentu. Populasi dalam penelitian ini adalah seluruh siswa SMP Negeri I Maluku Tengah tahun ajaran 2013/2014 terdiri dari 15 rombel yang berjumlah 388 siswa. Pengambilan sampel dalam penelitian menggunakan Stratified Random Sampling. Pada pengambilan sampel yang akan dirandom yaitu jumlah rombel pada populasi berdasarkan strata (tingkatan kelas).

\section{HASIL DAN PEMBAHASAN}

Hasil analisis statistik deskriptif menunjukan bahwa skor variabel lingkungan belajar antara 85-124, harga rat-rata sebesar 103,86 standar deviasi sebesar 7,85, median sebesar 103,00 dan modus sebesar 103. Sedangkan untuk distribusi frekuensi dapat dilihat pada tabel berikut.

Tabel 1. Distribusi Frekuensi dan Persentase Lingkungan Belajar Siswa SMP Negeri I Maluku Tengah

\begin{tabular}{|c|c|c|c|c|}
\hline No. & Interval Skor & Frekuensi & Persentase & Kategori \\
\hline 1 & $30-52$ & 0 & 0 & Sangat Rendah \\
2 & $53-75$ & 0 & 0 & Rendah \\
3 & $76-97$ & 18 & 19,8 & Baik \\
4 & $98-130$ & 72 & 80,2 & Sangat Baik \\
\hline
\end{tabular}

Hasil analisis statistik deskriptif diperoleh ukuran pemusatan tentang konsep diri siswa, yaitu: rata-rata skor sebesar 102,46 simpangan baku atau standar deviasi sebesar 8,08 median sebesar 102,50 dan modus sebesar 103 Hasil ini menunjukkan bahwa konsep diri siswa berkisar 84,124 persen. Sedangkan untuk distribusi frekuensi dapat dilihat pada tabel berikut. 
Tabel 2. Distribusi Frekuensi dan Persentase Konsep Diri Siswa SMP Negeri I Maluku Tengah

\begin{tabular}{|c|c|c|c|c|}
\hline No. & Interval Skor & Frekuensi & Persentase & Kategori \\
\hline 1 & $30-52$ & 0 & 0 & Sangat rendah \\
2 & $53-75$ & 0 & 0 & Rendah \\
3 & $76-97$ & 18 & 19,8 & Tinggi \\
4 & $98-130$ & 72 & 80,2 & Sangat tinggi \\
\hline \multicolumn{2}{|c|}{ Jumlah } & 90 & 100 & \\
\hline
\end{tabular}

Pada Tabel 2 di atas. Menggambarkan konsep diri siswa SMP Negeri I Maluku Tengah cenderung berada pada kategori Sangat tinggi.

Tabel 3. Distribusi Frekuensi dan HasilBelajar Biologi Siswa SMP Negeri I Maluku Tengah.

\begin{tabular}{|c|c|c|c|c|}
\hline No. & Interval Skor & Frekuensi & Persentase & Kategori \\
\hline 1. & $85-100$ & 4 & 4,4 & Sangat tinggi \\
\hline 2. & $65-84$ & 13 & 15,3 & Tinggi \\
\hline 3. & $45-64$ & 31 & 34,3 & Sedang \\
\hline 4. & \multirow[t]{2}{*}{$350-34$} & 22 & 24,0 & Rendah \\
\hline 5. & & 20 & 22,0 & Sangat rendah \\
\hline & Jumlah & 90 & 100,00 & \\
\hline
\end{tabular}

Tabel di atas menunjukkan bahwa hasil belajar biologi siswa SMP Negeri I Maluku termasuk dalam kategori sedang. Berdasarkan hasil regresi Linier sederhana diperoleh $F_{\text {hitung }}$ sebesar 13,331 dengan tingkat signifikansi 0,000 yang kurang dari 0,05, bahwa semakin baik lingkungan belajar maka semakin tinggi pula hasil belajar biologi siswa. diperoleh $\mathrm{F}_{\text {hitung }}$ sebesar 24,865 dengan tingkat signifikansi 0,000 yang kurang dari taraf signifikansi $\alpha=0,05$. menunjukkan bahwa semakin tinggi konsep diri maka semakin tinggi pulahasil belajar biologi siswa, diperoleh $F_{\text {hitung sebesar 16,287 dengan tingkat }}$ signifikansi 0,000 yang kurang dari $\alpha=0,05$. Disimpulkan bahwa semakin tinggi pengaruh lingkungan belajar dan konsep diri secara bersamaan maka semakin tinggi pula hasil belajar siswa. Hal ini disebabkan karena ada 8 kecerdasan jamak yang dikemukakan oleh Gardner (1983) turut berperan dalam pencapaian hasil belajar siswa selain faktor internal dan faktor external siswa yaitu: kecerdasan natural dan kecerdasan intrapersonal, kecerdasan logika matematika, kecerdasan fisik, kecerdasan visual, kecerdasan interpesonal dankecerdasan musikal.

Kedelapan kecerdasan tersebut dapat saja dimiliki individu, hanya saja dalam taraf yang berbeda, selain pada anak terkadang memiliki lebih dari satu kecerdasan namun ada juga hanya memiliki satu kecerdasan sehingga dalam mencapai hasil belajar yang baik perlu peran dari keluarga. Ditemukannya pengaruh konsep diri terhadap hasil belajar sejalan dengan hasil penelitian Hawadi (2001) menyebutkan bahwa salah satu faktor dalam pencapaian prestasi belajar adalah konsep diri, yang menunjukan bagaimana seseorang memandang dirinya serta kemampuan yang dimiliki. 


\section{KESIMPULAN}

Kesimpulan dari penelitian ini: (1) Terdapat pengaruh yang signifikan antara lingkungan belajar terhadap hasil belajar biologi siswa SMP Negeri I Maluku Tengah (2); Terdapat pengaruh yang signifikan antara konsep diri terhadap hasil belajar biologi siswa SMP Negeri I Maluku Tengah; (3) Terdapat pengaruh yang signifikan antara lingkungan belajar dan konsep diri secara bersama-samaterhadap hasil belajar biologi siswa SMP Negeri I Maluku Tengah.

\section{DAFTAR PUSTAKA}

Ahmadi Abu dan Uhbiyat Nur. (1991). IlmuPendidikan. PT Rineka Cipta. Jakarta. Ahmadi dan Supriyono. (1991). PsikologiBelajar. PT RinekaCipta. Jakarta.

AnisaWidyaningtyas, Sukarmin, Yohanes Radiyono. 2013. Peran Lingkungan Belajar dan Kesiapan Belaja rterhadap Prestasi Belajar Fisika Siswa Kelas X Sekolah Menengah Atas Negeri1 Pati.JurnalPendidikan, (online), vol 1, No. 1, (http://www.Universitas Sebelas Maret.ac.id. Diakses April 2013)

Arikunto Suharsimi. (2006). ProsedurPenelitianSuatuPendekatanPraktik. Rineka cipta. Jakarta.

Baharudin dan EsaNurWahyuni. (2007). Teori Belajar dan Pembelajaran. Ar-Ruzz Media. Jogjakarta: 